\title{
Work in Rotating Shifts and its Effects on the Daily Life of Grain Processing Workers
}

\author{
Mariana Roberta Lopes Simões \\ Flávia Cristina Marques² \\ Adelaide de Mattia Rocha ${ }^{3}$
}

\begin{abstract}
This study aimed to investigate the effects of alternating shift work in the daily life of grain processing workers. A quantitative data collection research was carried out at a grain processing company in Goiás - Brazil. Research participants were 53 alternating shift workers. A questionnaire was developed and used for data collection, based on the principles of chronobiology and Pittsburgh Sleep Quality Index, with 31 closed and one open question. The result showed dissatisfactory sleep quality for approximately $50 \%$ of the participants. The most evidenced physiological changes referred to the digestive tract. As for behavioral aspects, irritability was highlighted. Among the research participants, $70 \%$ considered that their work hours affect their leisure and social life. In conclusion, negative manifestations exist in the daily life of people working in alternating shifts, which can affect their physical, mental and social health.
\end{abstract}

Descriptors: Shift Work; Occupational Health; Occupational Risks; Working Conditions.

\footnotetext{
${ }^{1}$ RN, Master's Student, Escola de Enfermagem, Universidade Federal de Minas Gerais, MG, Brazil. E-mail: mari_curvelo@yahoo.com.br.

${ }^{2}$ RN, Specialist in Occupational Health Nursing. E-mail: fravia23@hotmail.com.

${ }^{3}$ RN, Ph.D. in Nursing, Adjunct Professor, Escola de Enfermagem, Universidade Federal de Minas Gerais, MG, Brazil. E-mail: adelaide@enf.ufmg.br.
}

Corresponding Author:

Adelaide de Mattia Rocha

Universidade Federal de Minas Gerais. Escola de Enfermagem.

Departamento de Enfermagem Básica

Rua Alfredo Balena, 190 Sala 204

Bairro Santa Efigênia

CEP: 30130-100 Belo Horizonte, MG, Brasil

E-mail: adelaide@enf.ufmg.br 


\title{
O trabalho em turnos alternados e seus efeitos no cotidiano do trabalhador no beneficiamento de grãos
}

Objetivou-se identificar os efeitos do trabalho em turnos alternados, no cotidiano dos trabalhadores no beneficiamento de grãos. Foi realizada pesquisa de coleta de dados, com abordagem quantitativa, em uma empresa de beneficiamento de grãos em Goiás, Brasil. Participaram da pesquisa 53 trabalhadores de turnos alternados. Foi elaborado e utilizado um questionário para a coleta de dados, baseado nos princípios da cronobiologia e no índice de qualidade do sono de Pittsburgh, com 31 questões fechadas e uma aberta. O resultado evidenciou que a qualidade de sono não é satisfatória para $50 \%$ dos participantes. As alterações fisiológicas mais evidenciadas se referiram ao trato digestivo. Quanto aos aspectos comportamentais, a irritabilidade foi destacada. Dos pesquisados, $70 \%$ consideraram que o lazer e a vida social ficam prejudicados pelo horário de trabalho. Conclui-se que existem manifestações negativas no cotidiano de pessoas que trabalham em turnos alternados, podendo afetar sua saúde física, mental e social.

Descritores: Trabalho em Turnos; Saúde do Trabalhador; Riscos Ocupacionais; Condições de Trabalho.

\section{El trabajo en turnos alternados y sus efectos en lo cotidiano del trabajador que beneficia granos}

\begin{abstract}
Se tuvo por objetivo identificar los efectos del trabajo en turnos alternados en lo cotidiano de los trabajadores que benefician granos. Fue realizada una investigación de recolección de datos con abordaje cuantitativo en una empresa de beneficio de granos en Goiás - Brasil. Participaron de la investigación 53 trabajadores de turnos alternados. Fue elaborado y utilizado un cuestionario para la recolección de datos, basado en los principios de la cronobiología y en el Índice de Calidad del Sueño de Pittsburgh, con 31 preguntas cerradas y una abierta. El resultado evidenció que la calidad del sueño no es satisfactoria para $50 \%$ de los participantes. Las alteraciones fisiológicas más evidenciadas se refirieron al tracto digestivo. En cuanto a los aspectos de comportamiento, la irritabilidad fue destacada. De los investigados, $70 \%$ consideraron que el descanso y la vida social quedan perjudicados por el horario de trabajo. Se concluye que existen manifestaciones negativas en lo cotidiano de personas que trabajan en turnos alternados, lo que puede afectar su salud física, mental y social.

Descriptores: Trabajo por Turnos; Salud Laboral; Riesgos Laborales; Condiciones del Trabajo.
\end{abstract}

\section{Introduction}

Shift work has existed since the start of man's social life. Today, besides technological and economic reasons, shifts are increasingly introduced for the sake of attending to modern society. Besides essential services, the number of people working in shifts, at night or with irregular work hours is growing, in services functioning uninterruptedly to produce goods and other services that attend to the population's growing demands $^{(1)}$. This situation is more frequent in the so- called continuous processing industry, where production cannot be interrupted each day, given the characteristics of the production form itself.

In this study, "shift work" was defined as a type of work organization aimed at guaranteeing production continuity (of goods and/or services) thanks to the presence of different teams working at different times at the same work station(2). 
Generally, quite varying shift work scales are adopted and, in the same work environment, various scales can exist ${ }^{(1)}$.

Two basic forms of shift work exist:

- Permanent: shifts in which workers work the same hours for many yours or across their work life, i.e. they work each day at the same time, e.g. during the day only, or in the afternoon, or at nightfall, or during the night shift.

- Alternating or rotating: when workers work rotating shifts, i.e. all workers should work both morning and afternoon or night shifts. Rotation in this form of shifts can be slow or fast, depending on the work organization.

Although many people see shift work as a natural solution to the 24-hour activity maintenance problem, this work organization, which basically takes into account technical and economic reasons, conflicts with biological, family and community rhythms, impairing workers' health and social life.

For some authors ${ }^{(3-4)}$, living beings' temporal organization is detected through regular cycles in their functions. These cycles work independently from the organisms' exposure to environmental cycles, but are influenced by external factors like the light and dark phenomenon (day/night) or, in the case of man, the social factor, which formalizes habits like daily activity and nightly rest.

Like fixed night shifts, some studies also identify alternating shifts as a factor that maximizes negative effects on health, as it hampers any attempt to adapt the biological to the work rhythm ${ }^{(4-6)}$.

The disorder in the rhythm structure caused by alternating shift work entails direct consequences for the sleep-wake cycle and for organic systems ${ }^{(3,6-7)}$. People are obliged to modify their times for sleep, meals, leisure and others. In general, organic effects can include the worsening of diseases, greater susceptibility to harmful agents, tiredness, mental suffering, early aging and gastrointestinal alterations ${ }^{(3,5,8)}$.

Nevertheless, alternating shifts are used as an alternative for the permanent inversion of natural human rhythms imposed by fixed shifts like at night ${ }^{(1,3)}$. Little is known so far, however, about the particularities alternating shift organization can represent for workers' daily life, health and social life.

Various studies have attempted to understand workers' work and health relations from different perspectives. A consensus exists that work conditions determine the working population's way of living and getting ill. In other words, workers' life and health is constituted based on the dynamics of work, which in turn results from organizational issues ${ }^{(6,9-10)}$

In this context, discussing shift alternation, even in a specific group of workers, can contribute to a new look on a form of work organization that is so current and present in different production and service delivery sectors.

This study departs from the biological time concepts, according to which organic functions differ between day and night, so that alternating shift work implies alterations not only in social life, but also in workers' organism(11-12).

\section{Aims}

\section{General}

Get to know the effects of alternating shift work on the daily life of workers at a grain processing company.

\section{Specific}

- Identify whether the alternating shift workers present sleep-wake alterations;

- Identify whether sleep and rest needs are attended to;

- Identify whether workers keep up social contact when working in alternating shifts;

- Identify whether these workers present health alterations.

\section{Method}

A quantitative, observational and cross-sectional study with a descriptive approach was carried out.

Approval for the project was obtained from the Institutional Review Board at Faculdade São Camilo in Minas Gerais, registered under opinion No 059/08, after which data collection started.

Data were collected by applying a questionnaire among alternating (rotating) shift workers at a grain processing company located in São Simão, Goiás Brazil.

Information was organized and categorized using a Microsoft Office Excel worksheet. Basic statistical treatment, including percentage distribution and calculation of means, was used to present and discuss the results.

The company under analysis is part of a group dedicated at the industrialization of grains, ranging from seed production, storage, degermination, pre-cooking of corn, extraction and refinement of special soy, corn, sunflower and canola, as well as the production of 
bran. The work scale of alternating shift workers at this company is as follows: workers work morning periods consecutively for two days, followed by two days in the afternoon period, two days at night and two days of rest. In this type of rotation, the weekdays when workers are on leave are always changing, depending on compliance with the rotation, and do not necessarily fall on Sundays.

The company staff includes 233 workers, 68 of whom work in alternating shifts. The sample comprised 53 rotating shift workers who spontaneously answered the questionnaire after signing the informed consent term. Their functions are divided as follows: Production Operator, Front-End Loader Operator, Production Aid, Driver and Handler.

The questionnaire was elaborated with 31 closed and one open question. This self-applied data collection instrument was didactically subdivided in sociodemographic questions (age, gender, marital situation, number of children and others) and questions related to the circadian rhythm and worker's health.

To construct this instrument, the paradigms of chronobiology were used as a reference framework. This branch of contemporary biology studies the rhythmicity of biological functions, considering the variability of human activities during 24 hours, known as the circadian rhythm ${ }^{(4,13)}$. Besides, some components of the Pittsburg Sleep Quality Index (PSQI) were adapted, which is a structured form for subjective sleep assessment, addressing aspects like subjective sleep quality, sleep duration, use of sleep medication, daily sleepiness and wake disorders ${ }^{(14-15)}$.

The workers received the questionnaire together with the informed consent term, guaranteeing their voluntary participation and identity preservation.

\section{Results}

Data were collected in February 2009 during the company's shift meetings. The company's security technician delivered the questionnaires to the workers.

Fifty-three alternating shift workers answered the questionnaire, corresponding to $77.9 \%$ of all workers in this work scheme. Causes for non-participation in the research are divided as follows: Vacation (5\%), leave of absence (5\%) and could not or did not want to participate in the study (12\%).

All participants are men, $41.5 \%$ informed having children, $37.7 \%$ informed being single, followed by married (34\%), living with a fixed partner (24.5\%) and divorced (3.7\%). Ages ranged from 17 to 38 years, with 37 participants in the range between 20 and 28 years. As for education level, $11.3 \%$ of the workers finished primary education, $37.7 \%$ secondary education and $25 \%$ finished or were in higher education.

The workers' professional categories are divided as follows: Production Operator (47.9\%), Front-End Loader Operator $(9.4 \%)$, Production Aid (38.7\%), Handler (3.8\%).

In the study sample, $43 \%$ informed excessive sleepiness during the work journey, $13 \%$ used some kind of drink to stay awake and $49 \%$ had already used some medication to stay awake during the work period in the previous year. None of them informed any medication. The most common drinks mentioned were: coffee, CocaCola and guaraná powder.

Among the subjects, $51 \%$ confirmed frequent insomnia in the previous year and $11 \%$ mentioned sporadically using medication to sleep.

The workers subjectively attributed the mean score of 5.7 to their daily sleep quality, on a scale from 0 (zero) to 10 (ten), with $42 \%$ informing less than 6 hours of sleep per day.

Among the clinical manifestations mentioned in the research, $52.8 \%$ of the interviewees mentioned intestinal constipation, $43.3 \%$ heartburn, $43.3 \%$ irritability, $35.8 \%$ lack of appetite, $26.41 \%$ frequent headache and $68 \%$ subjectively considered the shift work factor harmful for their health.

With regard to the interaction between social life and alternating shift work, $70 \%$ of the interviewees considered that their work hours hamper their leisure and social life because it does not combine with their friends and relatives' hours. In total, $62.3 \%$ informed that rotating shift work is more tiresome than other forms, and $80 \%$ considered that leaves are insufficient to relax. In the study sample, $56.6 \%$ do not manage to conciliate their work hours with those of other people they live with.

On a scale ranging from excellent to good, regular, bad and very bad, $50 \%$ of the workers considered their work hours "regular" and 20\% considered they were "bad".

At the end of the research, the workers proposed some changes to improve their work condition. These suggestions were appointed, analyzed and, in general, included: fixation of work hours with at least six-month turnover and expansion of leaves. 


\section{Discussion}

The results reveal that the research participants showed negative manifestations in their daily life. In the sleep-wake cycle, most workers displayed sleepiness during work and difficulty to sleep, insomnia, during the rest period. Reports on medication use also stand out, to stay awake as well as to sleep. These findings alert to the increase in the risk of occupational accidents as well, as a result of these workers' declined concentration ability.

In general, these difficulties to adjust to the alternating sleep schedule are present in rotating shift workers. Consequently, difficulties to stay alert during work hours can result in reduced occupational performance or even make work more dangerous or risky ${ }^{(13)}$.

With regard to sleep, the alterations occurred due to shift work are attributed to the desynchronization of circadian rhythms, provoked by changes in the activityrest cycle $^{(7,16)}$.

Insomnia or shorter sleep periods are due to forced changes in sleep times, which sometimes occur during the day, and is extremely unfavorable due to the nonadaptation of biological rhythms to this inversion(7,13). Besides, daytime sleep quality is bad due to unfavorable environmental conditions, such as light, noise and domestic events, modifying the distribution of sleep phases and interfering in their restoring property(17). Even short periods of alteration in the circadian rhythm, such as hospitalization, can interfere in sleep quality, with varying times for recovery ${ }^{(18)}$

Bad-quality sleep provokes increased sleepiness during work, as observed in the research results. This sleepiness is often responsible for accidents, lack of interest, anxiety, irritability, efficiency loss and stress $^{(3,7,14)}$. Sleep disorders entail high social costs due to the increased risk of traffic accidents, abuse of sleep medication in case of insomnia, and medication to avoid sleeping, mainly among night-shift workers, contributing to a bad quality of life ${ }^{(19)}$.

We know that, to perform well, workers should be restful when they start working. Fatigue impedes good physical performance, decreases attention levels and considerably disturbs motor coordination and mental rhythm ${ }^{(3,13)}$. Therefore, sleep and rest gain particular importance for shift workers who, like in this research, operate machines or even work close to them.

With regard to the workers' perception of physical health alterations, gastrointestinal disorders like heartburn, gastritis and intestinal constipation stand out, among others. These problems generally appear due to the fact that workers do not have adequate meal times, frequently exchanging meals for snacks. Then, digestive disorders are generally attributed to irregular meal times and food types, as well as individual circadian rhythms' lack of synchronization ${ }^{(13)}$.

Another finding refers to the feeling of irritability, also enhanced by circadian rhythm disorder. In addition, there is the fact that irritability compromises professional and affective relations, besides increasing risks while performing their activities due to lack of attention ${ }^{3-}$ $4,7,13)$.

During a large part of their life, shift workers go against society, not only during night work, but also in the afternoon, weekend and holiday times. Alternating work hours entail great difficulties to program activities, always depending on the "new" work scale ${ }^{(13)}$. Compensation benefits like bonuses do not necessarily counterbalance the restrictions these workers face in their lives.

Negative interference in social life is one of the main problem sources for workers who submit to these work rhythms. When one is obliged to sleep when everyone's awake and work when the rest of society sleeps, workers cannot normally follow their relatives' life, entailing countless problems in their relationship with children and spouses, and for participation in organized social activities: study, leisure, union life, political life ${ }^{(7-8)}$.

Workers frequently complain about the harm caused by relative social isolation, activity discrimination and difficulties to conciliate their leave with that of their friends and relatives ${ }^{(1)}$

Social relationship difficulties are confirmed in the research subjects' suggestions, proposing, among other things, fixing shifts, at least per semester. Some studies appoint stakeholders' (employer and employee) interactive involvement in work scheme definition as a success factor in the work relation ${ }^{(1)}$.

\section{Conclusion}

For the study population, shift work showed to be a source of very important effects for their health, regarding physical, emotional and social (family and interpersonal) aspects.

Disturbing the circadian rhythm, alternating shift work entails negative implications for many selfregulated biological processes. One of the problems evidenced in this study was sleep-related. Among sleep 
disorders, insomnia, excessive sleepiness during work and medication use to stay awake at work showed to be especially important. Considering that the physical rest sleep provides is fundamental for the good performance of job activities, a historical conflict emerges here: on the one hand the satisfaction of economic and technical needs and, on the other, the worker's human needs.

The constant change in physiological patterns caused by alternating work hours showed to be related with manifestations like intestinal constipation, heartburn, lack of appetite and irritability.

The research subjects substantially reported on the negative interference of alternating shift work in workers' social life. These workers face difficulties to be present in family life and go out with friends, a fact that compromises their social and affective relations and can frustrate the family's expectations.

As the current society cannot stop, a growing number of workers face the need and difficulty to work in alternating or night shifts.

Due to this reality and the verification of both physical and social harm for workers, researchers and health professionals need to make continuing efforts to get to know find ways to organize the temporality of work so as to minimize the impacts of alternating work hours on workers' lives. Moreover, it is fundamental to put in practice active occupational health surveillance, complying with legal requirements for workers' health.

\section{References}

1. Moreno CRC, Fischer FM, Rotenberg L. A saúde do trabalhador na sociedade 24 horas. São Paulo Perspect. 2003; 17(1):34-46.

2. Silva CF. Ritmos biológicos e Trabalho por Turnos. Rec Hum Mag. [internet].2000; (6). [acesso 10 ago 2008). Disponível em: http://aeiou.expressoemprego.pt/scripts/indexpage. asp?headingID $=4160$.

3. Campos MLP, Martinho MMF. Aspectos cronobiológicos do ciclo vigília-sono e níveis de ansiedade dos enfermeiros nos diferentes turnos de trabalho. Rev Esc Enferm USP. 2004; 38(4):415-21.

4. Moreno CRC, Louzada FM. [O que acontece com o corpo quando se trabalha à noite?] Cad Saúde Pública. 2004;20(6):1739-45. Inglês.

5. Lima AMJ, Soares CMV, Souza AOS. Efeito da inversão dos turnos de trabalho sobre capacidade aeróbia e respostas cardiovasculares ao esforço máximo. Rev Bras Med Esporte. 2008;14(3):201-4.

6. Marziale MHP, Rozestraten RJA. Turnos alternantes: fadiga mental de enfermagem. Rev. Latino-Am. Enfermagem. 1995;3(1):59-78.

7. Rocha MCP, Martino MMF. Estresse e qualidade do sono entre enfermeiros que utilizam medicamentos para dormir. Acta Paul Enferm. 2009;22(5):658-65.

8. Ferreira LL. Trabalho em turnos: Temas para Discussão. Rev Bras Saúde Ocupacional. 1987;15(58):27-32.

9. Dal Pai D, Lautert L. O trabalho em urgência e emergência e a relação com a saúde das profissionais de enfermagem. Rev. Latino-Am. Enfermagem. 2008;16(3):439-44.

10. Elias MA, Navarro VL. A relação entre o trabalho, a saúde e as condições de vida: negatividade e positividade no trabalho das profissionais de enfermagem de um hospital escola. Rev. Latino-Am. Enfermagem. 2006;14(4):517-25.
11. Martinez D, Lenz MCS, Menna-Barreto L. Diagnóstico dos transtornos do sono relacionados ao ritmo circadiano. J Bras Pneumol. 2008;34(3):173-80.

12. Martinho MMF. Arquitetura do sono diurno e ciclo vigília-sono em enfermeiros nos turnos de trabalho. Rev Esc Enferm USP. 2009;43(1):194-9.

13. Gaspar S, Moreno C, Menna-Barreto L. Os plantões médicos, o sono e a ritmicidade biológica. Rev Assoc Med Bras. 1998;44(3):239-45.

14. Souza JC, Paiva T, Reimão R. Sono, qualidade de vida e acidentes em caminhoneiros Brasileiros e Portugueses. Psicol Estudo. 2008;13(3):429-36.

15. Backhaus J, Junghanns K, Broocks A, Riemann D. Test-retest reliability and validity of the Pittsburg Sleep Quality Index in primary insomnia. Psychosom Res. 2002;53(3), 737-40.

16. Martinez MAR, Oliveira LR. Trabalho em turnos nas empresas de Botucatu, São Paulo: estudo descritivo. Cad Saúde Pública. 1997;13(2):639-49.

17. Martino MMF. Estudo comparativo de padrões de sono em trabalhadores de enfermagem dos turnos diurno e noturno. Rev Panam Salud Pública. 2002;12(2):95-9.

18. Zaros MC, Ceolim MF. [Ciclo vigília/sono de mulheres submetidas a cirurgia ginecológica eletiva com um dia de hospitalização]. Rev. Latino-Am. Enfermagem. 2008; 16(5):83843. Inglês.

19. Inocente NJ. Paraíba Valley university teachers occupational stress: burnout, depression and sleep evaluation. Arq. NeuroPsiquiatr. [Internet]. 2005;[acesso 06 abr 2010]; 63(2a):367. Disponível em: http://www.scielo.br/scielo.php?script=sci_ arttext\&pid=S0004-282X2005000200035\&lng=pt. 